\title{
Biological and Chemical Investigations of Water Quality and Contamination Study After a Suspicious Algal Bloom in a Coastal Lagoon, Jeddah, Saudi Arabia
}

\author{
Ahmed Alansari ${ }^{1,2}$ \\ ${ }^{1}$ Environmental Affairs, The General Authority of Meteorology and Environmental Protection, \\ Jeddah 1358, P.O. Box 21431, and ${ }^{2}$ Department of Environmental Sciences, King Abdulaziz. \\ University, Jeddah 21598, P.O. Box 80208, Saudi Arabia
}

\begin{abstract}
The General Authority of Meteorology and Environmental Protection (GAMEP) started an investigation about suspicion of microcystis bloom with toxin production in lagoon near Obhour, Jeddah. Water samples were collected from different spots covering all lagoon directions. The samples were analyzed for salinity, coliforms, toxin producing microalgae using MPN, and microscopic examination. LC/MS-MS analysis was used to identify and quantify the extra-cellular microcystins (MCs) in the lagoon water. The results revealed complete absence of the toxic algae or its secreted toxins. The results revealed the presence of Dunaliella salina with rich $\beta$-carotene production responsible for brown or pink color in the lagoon.
\end{abstract}

Keywords: Fish coastal lagoon, Algal bloom, Duniliella salina, Jeddah, LC/MS-MS.

\section{Introduction}

Jeddah is known as the bride of the Red Sea because of its magnificent beaches and coastline which spans for about $30 \mathrm{~km}$ (Rasul et al., 2015). The recreational coast of Jeddah includes a number of famous semi-closed water bodies such as Al-Arbaeen, Al-Shabab, and Al-Salam lagoons (Al-Lihaibi, 2000). During the last three decades, as the city was developing and expanding, these three lagoons started to face environmental pressures and showed some singes of environmental degradation. Poor environmental management of municipal and industrial wastewater in addition to torrents streams was always among the top list root causes of Jeddah coast environmental deterioration (Jastaniah, 2010; Kitto and Sambhu, 2012).
In addition to the above mentioned lagoons, environmental issues emerged in other smaller lagoons recently, the lagoon with fish statue (Samaka) fetched public attention through social media with pink color and odor. The lagoon is located in the southern district of Obhur in Jeddah and was named after the presence of an aesthetic metal sculpture in the shape of a large fish (statue) in the middle of the artificial coastal lagoon (Fig. 1a). The area of the lagoon is estimated at $11,160 \mathrm{~m}^{2}$ and its depth is close to 2-3 meters (personal communications). The lagoon lacked the ideal biodiversity due to poor water exchange between its water and Sharm Obhur sea water. Despite its small size, the lagoon attracted media and community attention because of its elevated pollution. In mid-November 2017, environmental activists and media reports indicated the appearance of red or pinkish tide 
due to algae blooms that produce toxic chemicals. The media reports were based on descriptive laboratory observations that identified these algae by belonging to the family of cyanobacteria (unpublished data). The lagoon was blamed to be highly contaminated with a toxic algae.

Microcystins (MC) is a group of peptide toxins that are normally produced by the cells of the cyanobacterial blooms in fresh water. This type of monocyte is multiplying in lakes, ponds and stagnant water. MC consist of a number of congeners characterized by the presence of leucine (L), arginine (R) and tyrosine (Y) as L-amino acids in positions 2 and 4. Based on acute toxicity of MC variants were classified as MC-LR, MC-LA, MC-RR, MC-YR, MC-YA, MC-AR and MC-M(O)R (Zurawell et al., 2005). The most commonly occurring MC congeners were MC-LR, MCYR and MC-RR, where MC-LR was reported to be highly toxic among the three congeners (Li et al., 2017). Once the cyanobacterial cell dies, the toxins get released and solubilized in the surrounding waters (White et al., 2005., Ye et al., 2017). The environmental half-life of MC was reported to be 90-120 days in natural water and a maximum of 50 days in sediment. The environmental persistence of $\mathrm{MC}$ is dependent on different environmental factors such as light penetration, algal bloom, oxic and anoxic conditions (Welker and Steinberg, 2000, Holst et al., 2003., Zastepa, 2014). Exposure of MCs (either acute or chronic phase) leads to severe liver damage and results in tumor formation (Grosse et al., 2006, Li et al., 2011., Fujiki and Suganuma, 2011). MCs were also reported as potential human carcinogens (Lone et al., 2015). The liver is the target organ of MCs in exposed organisms including fish, mammals and birds. Humans could also be exposed to such toxins through swimming and/or the involving in some marine sport activities (Drobac et al., 2013).
MCs may also bio-accumulate in food chain and hence humans could be exposed to trace levels via the ingestion of contaminated food as well (Larson et al., 2014; Greer et al., 2018). Mortality cases of animals such as dogs, cows, and birds were linked to the consumption of water contaminated with such toxins (Hilborn and Beasley, 2015.; Backer and Miller, 2016). Symptoms of human exposure to MCs include skin rashes, ear and eye irritation, asthma, allergic reactions, sporadic dry cough, vomiting, diarrhea, abdominal pain, pneumonia. MCs were also reported to cause liver damage and acute illness such as myalgia, severe headache, vertigo and blistering in the mouth (Stewart et al., 2006.; Drobac et al., 2013). The World Health Organization (WHO) considered oral ingestion as the main root to MCs in humans and thus estimated a tolerable daily intake (TDI) value of $1.5 \mathrm{mg} \mathrm{L}^{-1}$ via drinking water and $0.04 \mathrm{mg} \mathrm{kg}^{-1}$ body weight (WHO, 2004).

In response to public concerns the General Authority for Meteorology and Environmental Protection (GAMEP) and Jeddah Municipality signed a cooperation agreement to deal with the pollution of the coastal lagoon (fish statue). According to the agreement and as a precaution measure to protect the general public, it was assumed that the change in the lagoon color was due to the growth of a toxic algal bloom. Accordingly, the site of the lagoon was monitored and the public was prevented from approaching, and each party exercised its functions according to the provisions of the convention document. As the agreement emphasized, GAMEP was in charge of conducting a comprehensive study of the lagoon to identify the root causes of its pollution and provide Jeddah Municipality with a scientific report illustrating the methods of control, treatment and optimal rehabilitation of the lagoon. As part of the comprehensive study, the main aim of this paper was to: i) 
determine the biological characteristics of the lagoon water ii) identify the cause of coloration in the lagoon water and iii) test the hypothesis of the presence of MC in the coastal lagoon water by a sophisticated chemical analysis approach.

\section{Materials and Methods}

\subsection{Sample Collection}

A total number of 25 lagoon water samples were collected in different occasions during the study time frame (November 11 2017 to February 01, 2018) for both biological and chemical analysis. For biological characterization, the water samples mixed with salt flakes, algae and sediments were collected in sterile Schott Duran bottles $(250 \mathrm{~mL})$ from all four directions of the lagoon. A total of sixteen (eight/sampling) samples were collected during first and second sample collection. Nine samples were collected in the third sample collection which includes the center of the lagoon (Fig. 1b). The samples were labeled appropriately based on the directions (North, South, East and West) with glass marker. The samples were collected by following appropriate safety protocol such as wearing the safety mask and hand gloves. The samples were collected using the sampling stick fitted with 1L sampling mug. For microbiological analysis, pre-sterilized (autoclaved at $121{ }^{\circ} \mathrm{C}$ at $15 \mathrm{lbs}$ for $15 \mathrm{~min}$ ) Schott Duran bottles $(250 \mathrm{~mL})$ were used to collect the samples. The temperature of the lagoon was recorded as $\left(25^{\circ} \mathrm{C} \pm 2{ }^{\circ} \mathrm{C}\right)$. All the samples were stored in the sampling box with ice pack and transported from the sampling site to the Center of Excellence in Environmental Studies (CEES) laboratories at King Abdulaziz University (KAU). For chemical analysis, a total of 30 grab sample were collected from the coastal lagoon in plastic bottles with 2L capacity (Table 1). Samples were transported from the field in ice box to the department of Environmental Sciences laboratories at KAU. Upon arrival, all samples were wrapped in tin foil and refrigerated at $4{ }^{\circ} \mathrm{C}$ until ready for further processing.
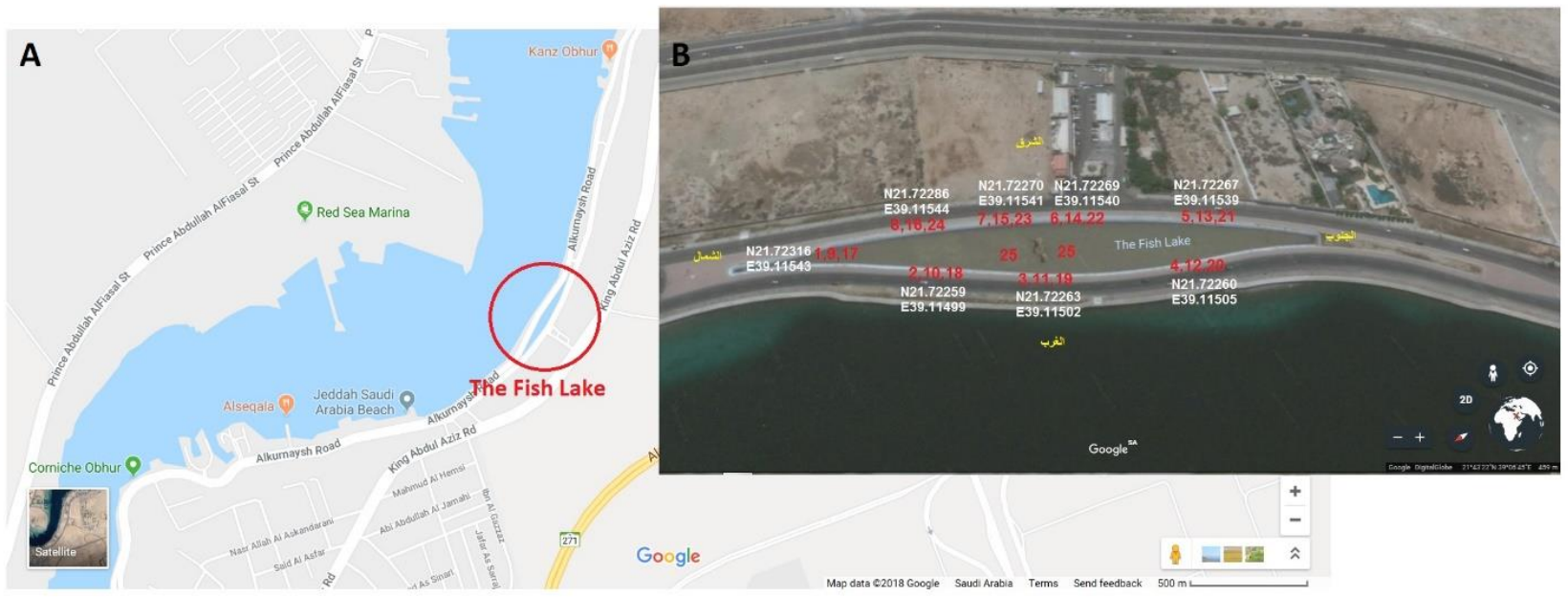

Fig. 1. A) Shows a general overview of the Fish Lagoon within Obhur Bay, B) Sampling locations from the Fish Lagoon and the coast of Obhur Bay. 
Table 1. Average physicochemical parameters data for the whole lagoon water $(n=25)$.

\begin{tabular}{|l|l|l|}
\hline Parameters & $\begin{array}{l}\text { GAMEP ambient red sea water } \\
\text { quality standard level }\end{array}$ & Lagoon water quality (Average) \\
\hline \multicolumn{2}{|c|}{ Physicochemical parameters } \\
\hline Temperature & - & $25^{\circ} \mathrm{C}$ \\
\hline $\mathrm{pH}$ & - & 8.18 \\
\hline Salinity (\%) & 3.9 to 4 & 11 \\
\hline Dissolved oxygen (mg/L) & $>5$ & 8.57 \\
\hline Electrical conductivity (mS/cm) & - & 117.3 \\
\hline Total Dissolved Solids (TDS)-mg/L & 37000 to 45000 & 117000 \\
\hline
\end{tabular}

\subsection{Sample Preparation and Analysis}

Initial physico-chemical parameters such as $\mathrm{pH}$, temperature, electrical conductivity, dissolved oxygen, salinity and total dissolved solids were analyzed immediately after sample collection (Table 1). Biological parameters such as bacterial cell count, total coliform, fecal coliform, E. coli (Harrigan, 1998) and identification and quantification of algae were performed. Pour plate technique with nutrient agar was used for total viable bacterial count (Harrigan, 1998). All plates including control were incubated at $37{ }^{\circ} \mathrm{C}$ and viable colony count as colony forming unit $(\mathrm{cfu} / \mathrm{mL})$ was performed after $24-48 \mathrm{~h}$ of incubation. Coliform analysis was performed by using most probable number (MPN) technique as per standard methods detailed in APHA (2005). Algal samples collected in algal net and mounted under light microscope for qualitative and quantitative analysis. Based on the morphology of the algal species the identification was executed. The slide used for algal quantification consist of one hundred boxes with the holding capacity of $1 \mathrm{~mL}$ sample, where around ten boxes will be counted on each direction. Average of the ten boxes was calculated for $1 \mathrm{~mL}$ of sample.

Sample preparation steps to determine the concentration of the extracellular $\mathrm{MC}$ in the lagoon water by liquid chromatographytandem mass spectrophotometry (LC-MS/MS) were completed within a week after sample collection. All samples were filtered using
Whatmann filter paper Grade $(0.45 \mu \mathrm{m})$ and extracted by solid phase extraction cartridges (SPE: Oasis HLB 20cc). The SPE columns were conditioned with $12 \mathrm{~mL}$ methanol followed by $12 \mathrm{~mL}$ MilliQ water and then samples were loaded on the SPE cartridges using a vacuum manifold system at a flow rate of $8 \mathrm{~mL} / \mathrm{min}$. After the extraction was completed, the SPEs were vacuum dried for 30 min prior to shipment to the laboratory of natural and synthetic environmental toxins (LANSET) (University of Ottawa, Canada) for chemical analysis by LC-MS/MS.

In LANSET, all SPE cartridges were eluted with $6 \mathrm{ml}$ of LC/MS grade methanol, centrifuged at 3000 RPM and filtered through $0.22 \mu \mathrm{m}$ PTFE (Polytetrafluoroethylene) syringe filters. Chemical analysis was accomplished according to Zastepa et al. (2015). Briefly, separations were performed on a Shimadzu LC20 series high performance liquid chromatography hyphenated with a 4000 QTRAP MS system (AB SCIEX, Concord, ON, Canada). Reversed phase chromatography was performed on a Phenomenex Luna ${ }^{\circledR}$ PFP (2) LC Column (100 $\mathrm{mm} \times 2.0 \mathrm{~mm}$ I.D., particle size $3 \mathrm{~mm}$ ). The column thermostat was maintained at $40{ }^{\circ} \mathrm{C}$. The sample volume of $5 \mu \mathrm{L}$ was injected for analysis. The flow rate was maintained 0.6 $\mathrm{mL} / \mathrm{min}$ with an initial mobile phase composition of $90 \%$ A (water with $0.1 \%$ formic acid) and 10\% B (acetonitrile with $0.1 \%$ formic acid), linearly changing to $100 \%$ 
$\mathrm{B}$ in $8 \mathrm{~min}$, followed by a hold at $100 \% \mathrm{~B}$ for 2 min. Starting conditions were re-established over an additional $3 \mathrm{~min}$. Analyst software (version 1.6.3) was used for data acquisition. Source conditions were: temperature $350{ }^{\circ} \mathrm{C}$, voltage $+4500 \mathrm{~V}$, curtain gas (N2) pressure 20 psi, and the collision-induced dissociation gas (N2) set as medium. The authentic MC standards (>95\% purity) were analyzed in this study included MC-LR (LR; CAS: 101043-372), MC-7dmLR (7dmLR; 134842-07-2), MCRR (RR; 111755-37-4), MC-YR (YR; 10106448-6), MC-WR (WR; 138234-58-9), MC-LA (96180-79-9), MC-LY (LY; 123304-10-9), MC-LW (LW; 157622-02-1), and Nodularin (NOD; 118399-22-7). The instrument detection limit was $0.05 \mathrm{ng}$ (on column load). Stock solutions were prepared at $1 \mathrm{mg} / \mathrm{mL}$ and diluted serially to $10 \mathrm{ng} / \mathrm{mL}$. Quantitation was attempted based on area under the peak using external calibration curves $(0.05-5 \mu \mathrm{g} / \mathrm{ml})$.

\section{Results and Discussion}

\subsection{Microbiological Analysis of the Lagoon Water Samples}

The microbiological analysis covered the bacterial cell count, total coliform, fecal coliform, Escherichia coli (E. coli), and identification and quantification of algae.

\subsubsection{Coliform analysis}

The results of coliform analysis revealed that total coliform load was high in south east (SE) and south west (SW) regions of the lagoon where a sewage leak was found (Fig. 2). The presence of fecal coliform and E. coli in this region solidly confirmed the sewage contamination at this spot (SE and SW). Southern region of the lagoon was highly contaminated with the coliforms to a highest level of 5022 MPN/100 mL (Table 2).

The coliform analysis confirmed the presence of total and fecal coliform in the lagoon strongly due to disposal or leak of sewage waste into the lagoon. The results of coliforms were in correspondence with the bacterial cell count. The coliform contamination reached the center of the lagoon, which was confirmed by the presence of total, fecal coliforms and $E$. coli in the samples obtained from center of the lagoon. This sewage contamination leads to bad odor problem in the lagoon.

\subsubsection{Identification and quantification of algal strains in the lagoon}

The study on algal analysis established the presence of marine algae Dunaliella salina which was the sole responsible for the brownish color of the lagoon. Production of $\beta$ carotene by Dunaliella salina gave brownish and pink color shade to the lagoon. Apart from Dunaliella salina, algal species such as Nitzschia, Holopedium, and Spirulina were found in the lagoon samples (Table 3). The algal analysis results revealed the absence of microcystin producing fresh water algae such as Microcystis, Oscillatoria, Planktothrix, Nostoc and Anabena. Abundant amount of $\beta$ carotene producing Dunaliella salina (400 cells/mL of sample) was present in the contaminated coastal lagoon (Table 3). Dunaliella salina is a halophilic microalgae present in the high saline condition (salt evaporation ponds) with $\beta$-carotene and glycerol production (McGenity and Oren, 2012).

The carotenoids produced by the algae were used in pharmaceutical, cosmetics and dietary products (Niranjana et al., 2015; Sathasivam et al., 2018) $\beta$ carotenes were reported to be precursors for vitamin A (Xu et al., 2018). A 100 years of research was performed on Dunaliella salina reported the survival under hyper saline condition (Liska et al., 2004; Oren, 2005). The enhancement of $\beta$ carotene production by Dunaliella salina in the high saline coastal lagoon could be 
considered as a novel solution after the proper rehabilitation of the lagoon and an investment opportunity for Jeddah municipality.

The next dominant algal strain present in the saline coastal lagoon was identified as Spirulina (80 cells/mL of sample). The bioproducts pertained from Spirulina also consist of several health benefits such as protein rich superfood, enhance cell regeneration, fights aging, anti-fungal, anti-bacterial and also fight against cancer (Deng and Chow, 2010.; Mishra et al., 2014). Spirulina was also reported as food material with $70 \%$ protein and remaining part consist of vitamins (B12 and $\beta$ carotene) and minerals (iron).

Lack of cellulose cell walls in Spirulina make them feasible for easy digestion (Dillon et al., 1995). Spirulina act as antioxidants in comparison with blue barriers (Hampson, 2017).

Therefore, the present study revealed that the coastal lagoon is characterized by its richness of two marine algae, which could have economical values.

\subsection{Influence of Salinity on MC Producing Algae}

The salinity of the lagoon ranged from 41 to $160 \mathrm{~g} / \mathrm{L}, \mathrm{NaCl}$ during the three sampling sessions with an average of $110 \mathrm{~g} / \mathrm{L}$ (Table 4). The northern part of lagoon recorded high salinity ranging from 120 to $160 \mathrm{~g} / \mathrm{L}, \mathrm{NaCl}$ and followed by Middle East (ME) with 110 to $150 \mathrm{~g} / \mathrm{L}, \mathrm{NaCl}$. High salinity of the lagoon was due to accumulation of salt from the sea water and evaporation of water. Salinity was found to be less in the areas where the sewage contamination occurred due to improper disposal and leak in the discharge tube of sewage. Thus, the leak in the sewer line diluted the salinity in southern (SW and SE) part of the lagoon $(41$ and $70 \mathrm{~g} / \mathrm{L})$. The results of salinity also confirmed the absence of the toxic algae. The harsh environmental condition in the lagoon water exceeded the tolerance limit for the microcystis algae (Martin-Luna et al., 2015).

S1-Sampling 1, S2-Sampling 2 and S3 Sampling 3

Overall average salinity of all the lagoon samples was $109.56 \mathrm{~g} / \mathrm{L}(110 \mathrm{~g} / \mathrm{L})$

\subsection{Microcystin (MC) Analysis in the Lagoon Water}

The chemical analysis performed by a highly sensitive LC-MS/MS method revealed that none of the nine MC congeners (MC-LR, MC-7dmLR, MC-RR, MC-YR, MC-WR, MCLA, MC-LY, MC-LW, and NOD) was detected in any sample $(\mathrm{n}=30)$ above $0.05 \mathrm{ng}$ (on the column load). The analysis showed the absence of any extracellular MC levels in the Fish Lagoon water samples, which further confirmed the absence any harmful microcystis algal bloom during the time course of this study. The pinkish to brownish pigmentation of the lagoon water was due to the presence of highly populated Dunaliella salina algal strain (Fig. 3a, 3b and 3c) as illustrated above. The tolerance limit for the MC producing algae (Microcystis aeruginosa) was reported to range from 0.5 to $17 \mathrm{~g} / \mathrm{L}$ of $\mathrm{NaCl}$ (Martin-Luna et al., 2015). Furthermore, positive correlation between salinity and MC toxin release was suggested (Preece et al., 2017). In the current study, the lagoon water was characterized by very high salinity ranging from 40 to $160 \mathrm{~g} / \mathrm{L}, \mathrm{NaCl}$ which could easily lyse the cyanobacterial cells and hence increase the water levels of MC (Preece et al., 2017). A typical water concentration of MC during microcystis blooming event could range from the detection limits up to 1800 $\mu \mathrm{g} / \mathrm{L}$ (WHO, 1999) and a maximum concentration of $\mathrm{MC}(150,000 \mu \mathrm{g} / \mathrm{L})$ was reported in a lake at Kansas by United states geological survey (Graham et al., 2012). Accordingly, if presence of pink to red color seen in the lagoon water was due to the 
blooming of toxin producing cyanobacterial cells, MC would persistence for a minimum duration of three months (Welker and Steinberg, 2000; Holst, et al., 2003.; Zastepa, 2014), which was not the case in this study since MC was not detected even when the pink water samples (Fig. 3c) were collected during or just after the claimed blooming. Furthermore, since the coastal lagoon contained no fish or any other marine species it was difficult to link any mortalities to any suspected harmful algal bloom during the lagoon coloration. A simple risk assessment of human exposure to $\mathrm{MC}$ from the lagoon would require setting some assumptions. Since the lagoon ecology was not suitable for fishing or any other sport activities, the only recreational activity that may result in human exposure would be setting or walking close to the lagoon. Through such route, MC contaminated aerosols may affect humans. However, the duration of such activities was usually no more than few hours with negligible probable health threats. In the present study the results clearly revealed no contamination of $\mathrm{MC}$ in the coastal lagoon. The study also detailed the sewage contamination in the coastal lagoon which is still a threat to the environment. Thus, GAMEP proposed to stop sewage leak and rehabilitation of the coastal lagoon for bioenergy production from the dominant algal strains.

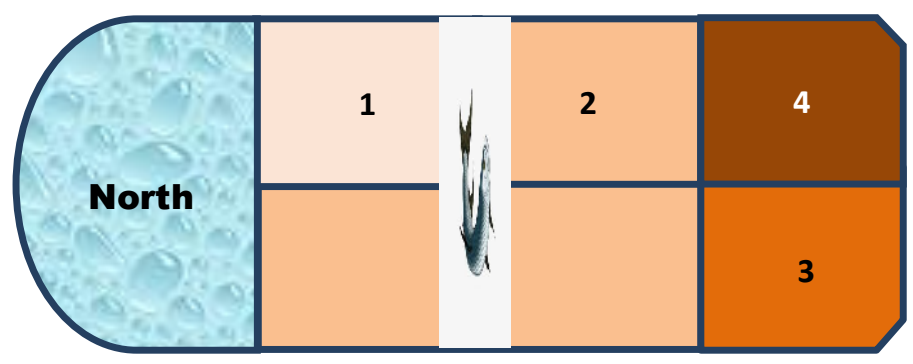

Fig. 2. Coliform contamination in the Fish Lagoon. Level of contamination represented in different colors and codes, 1: Lowest polluted area, 2: Medium polluted, 3: highly polluted, 4: Extremely polluted.

Table 2. Comparison of the lagoon microbial water quality results with the existing water quality standards by GAMEP (General Authority of Meteorology and Environmental Protection).

\begin{tabular}{|l|l|l|}
\hline Parameter & Lagoon water quality $(\mathbf{n = 2 5})$ & $\begin{array}{l}\text { GAMEP ambient red sea } \\
\text { water quality standard level }\end{array}$ \\
\hline Total Bacterial Cell count $(\mathrm{cfu} / \mathrm{mL})$ & $\begin{array}{l}\left.10^{6} \text { (Sewage contaminated regions- } 2,3 \text {, and } 4\right) \\
10^{3} \text { to } 10^{5} \text { (Other part of lagoon) }\end{array}$ & $<500$ \\
\hline Total coliform $(\mathrm{MPN} / 100 \mathrm{~mL})$ & $809(4.5$ to 5022$)$ & $<200$ \\
\hline Fecal coliform $(\mathrm{MPN} / 100 \mathrm{~mL})$ & $260(4.5$ to 986$)$ & $<200$ \\
\hline E.coli $(\mathrm{MPN} / 100 \mathrm{~mL})$ & $139(4.5$ to 679$)$ & $<500$ \\
\hline
\end{tabular}

Table 3. Quantitative analysis of algal strains in the coastal water sample.

\begin{tabular}{|l|l|c|c|c|c|}
\hline Sample Directions & \multirow{2}{*}{ Algae/ Sampling } & \multicolumn{4}{|c|}{ Algal Count (cells/mL) } \\
\cline { 3 - 6 } & & First & Second & Third & Average \\
\hline \multirow{5}{*}{ North } & Dunaliella Salina & $\mathbf{5 0}$ & $\mathbf{1 6 0}$ & $\mathbf{8 0}$ & $\mathbf{9 6 . 6}$ \\
\cline { 2 - 6 } & Nitzschia & 30 & 50 & 30 & 36.6 \\
\cline { 2 - 6 } & Synedra & 20 & 20 & 10 & 16.6 \\
\cline { 2 - 6 } & Cocconeis & 20 & 0 & 0 & 6.6 \\
\cline { 2 - 6 } & Holopedium & 10 & 0 & 10 & 6.6 \\
\hline
\end{tabular}




\begin{tabular}{|c|c|c|c|c|c|}
\hline \multirow[t]{4}{*}{ West } & Dunaliella Salina & $\mathbf{5 0}$ & 40 & 60 & 50 \\
\hline & Nitzschia & 20 & 20 & 20 & 20 \\
\hline & Navicula & 10 & 20 & 30 & 20 \\
\hline & Diploneis & 20 & 10 & 20 & 16.6 \\
\hline \multirow[t]{5}{*}{ Middle west } & Dunaliella Salina & 30 & 60 & 60 & 50 \\
\hline & Nitzschia & 20 & 20 & 20 & 20 \\
\hline & Cocconeis & 20 & 0 & 0 & 6.6 \\
\hline & Holopedium & 0 & 60 & 60 & 40 \\
\hline & Skeletonema & 10 & 0 & 10 & 6.6 \\
\hline \multirow[t]{10}{*}{ South West } & Dunaliella Salina & 50 & 400 & 260 & 236.6 \\
\hline & Nitzschia & 20 & 80 & 60 & 53.3 \\
\hline & Cocconeis & 20 & 50 & 30 & 33.3 \\
\hline & Skeletonema & 10 & 20 & 0 & 10 \\
\hline & Spirulina & 30 & 0 & 20 & 16.6 \\
\hline & Synedra & 10 & 0 & 0 & 3.3 \\
\hline & Dunaliella Salina & $\mathbf{0}$ & 100 & 90 & 63.3 \\
\hline & Nitzschia & 20 & 10 & 20 & 16.6 \\
\hline & Navicula & 50 & 40 & 30 & 40 \\
\hline & Spirulina & 30 & 40 & 40 & 36.6 \\
\hline \multirow[t]{4}{*}{ Middle East1 } & Dunaliella Salina & 100 & 90 & 110 & 100 \\
\hline & Nitzschia & 0 & 100 & 60 & 53.3 \\
\hline & Spirulina & 80 & 80 & 80 & 80 \\
\hline & Navicula & 70 & 0 & 40 & 36.6 \\
\hline \multirow[t]{3}{*}{ Middle East2 } & Dunaliella Salina & 80 & 80 & 90 & 83.3 \\
\hline & Spirulina & 0 & 40 & 20 & 20 \\
\hline & Nitzschia & 50 & 50 & 40 & 46.6 \\
\hline \multirow[t]{5}{*}{ North East } & Dunaliella Salina & 60 & 90 & 180 & 110 \\
\hline & Nitzschia & 40 & 140 & 80 & 86.6 \\
\hline & Spirulina & 0 & 30 & 10 & 13.3 \\
\hline & Holopedium & 30 & 0 & 10 & 13.3 \\
\hline & Diplonesis & 30 & 0 & 0 & 10 \\
\hline \multirow[t]{5}{*}{ Center } & Dunaliella Salina & 150 & 110 & 100 & 120 \\
\hline & Nitzschia & 20 & 20 & 30 & 23.3 \\
\hline & Spirulina & 60 & 50 & 50 & 53.3 \\
\hline & Navicula & 20 & 10 & 20 & 16.6 \\
\hline & Cocconeis & 10 & 0 & 10 & 6.6 \\
\hline
\end{tabular}

Table 4. Salinity analysis of the coastal lagoon water samples.

\begin{tabular}{|c|c|c|c|c|}
\hline \multirow{2}{*}{ Sample ID } & \multicolumn{4}{|c|}{ Salinity (g/L) } \\
\cline { 2 - 5 } & S1 & S2 & S3 & Average \\
\hline S1-N & 160 & 120 & 130 & 136.6 \\
\hline S2-W & 150 & 120 & 120 & 130 \\
\hline S3-MW & 120 & 100 & 110 & 110 \\
\hline S4-SW & 90 & 70 & 68 & 76 \\
\hline S5-SE & 70 & 41.1 & 42 & 50.3 \\
\hline S6-ME1 & 120 & 110 & 120 & 116.6 \\
\hline S7-ME2 & 140 & 120 & 120 & 126.6 \\
\hline S8-NE & 150 & 120 & 120 & 130 \\
\hline Center & 110 & 110 & 110 & 110 \\
\hline
\end{tabular}



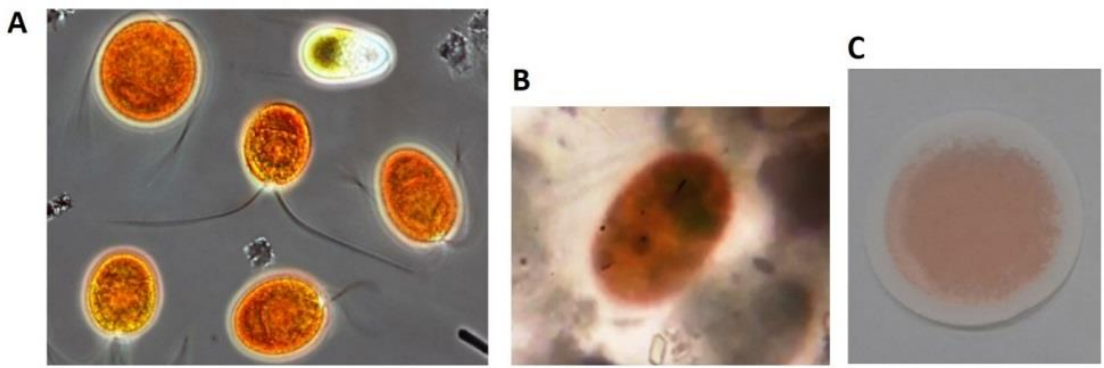

Fig. 3. A) Typical Dunaliella salina under fluorescence microscope obtained from MedSalt (https://medsalt.eu/fig-20-5a-bigger/), B) Picture of Dunaliella salina taken at CEES under light microscope using digital camera, C) A representative filter paper during sample preparation for MC analysis showing the fish lagoon water color (samples were collected November $20^{\text {th }}$, 2017).

\section{Conclusions}

The results of the chemical and microbiological analysis of the coastal lagoon water samples confirmed the absence of toxic MCs. Still the lagoon was contaminated with sewer line leakage which resulted in color and odor problem. GAMEP asked Jeddah municipality to inspect the sewer leakage in the coastal lagoon and to stop the release of the sewage water with appropriate sealing technology. GAMEP proposed the following ways to rehabilitate the coastal lagoon by i) Dilution of the lagoon with low saline water to reduce the salinity, ii) Growing halophytes in this region for bioenergy production and iii) enhancing the cultivation of Dunaliella salina and Spirulina for production of $\beta$-carotene (Precursor to vitamin A) and single cell protein which generate revenue to the ministry.

\section{Acknowledgments}

The author would like to thank GAMEP for funding this study, CEES at KAU, and LANSET at Ottawa U., for conducting the field work and analysis and Jeddah municipality for their cooperation.

\section{References}

Al-lihaibi, S.S. (2000). Petroleum hydrocarbons in sediments from Jeddah coast of Saudi red sea following the 1996 fuel oil spill. Journal of King Abdulaziz University: Marine Science, 11: 27-41.

APHA (2005). Standard Methods for the Examination of Water and Wastewater, 21st edn. American Public Health Association, Washington.

Backer, L.C. and Miller, M. (2016). Sentinel animals in a one health approach to harmful cyanobacterial and algal blooms. Veterinary Sciences, $3(2)$ : 8 . http://doi.org/10.3390/vetsci3020008.

Deng, R. and Chow, T.J. (2010). Hypolipidemic, antioxidant and anti-inflammatory activities of microalgae Spirulina. Cardiovascular Therapeutics, 28(4), e33-e45. http://doi.org/10.1111/j.1755-5922.2010.00200.x.

Dillon, J.C.; Phuc, A.P. and Dubacq, J.P. (1995). Nutritional value of the alga Spirulina. World Review of Nutrition and Dietetics, 77: 32-46.

Drobac, D.; Tokodi, N.; Simeunović, J.; Baltić, V.; Stanić, D. and Svirčev, Z. (2013). Effects of cyanotoxins in humans. Arh Hig Rada Toksikol, 64:305-316.

Fujiki, H. and Suganuma, M. (2011). Tumor promoters microcystin-LR, nodularin and TNF-a and human cancer development. Anticancer Agents Med. Chem., 11 (1): 418.

Graham, J.L.; Ziegler, A.C.; Loving, B.L. and Loftin, K.A. (2012). Fate and Transport of Cyanobacteria and Associated Toxins and Taste-and-Odor Compounds from Upstream Reservoir Releases in the Kansas River, Kansas, September and October 2011. U.S. Geological Survey Scientific Investigations Report, 5129: 65-66.

Greer, B.; Meneely, J.P. and Elliott, C.T. (2018) Uptake and accumulation of Microcystin-LR based on exposure through drinking water: An animal model assessing the human health risk. Scientific Reports 8:4913| DOI:10.1038/s41598-018-23312-7.

Grosse, Y.; Baan, R.; Straif, K.; Secretan, B.; El-Ghissassi, F. and Cogliano, V. (2006). Carcinogenitcity of nitrate, nitrite, and cyanobacterial peptide toxins. Lancet Oncol. 7: $628-629$. 
Hampson, B.C. (2017). Spirulina (Arthrospira platensis) as food: A commodity to better feed the world, J Food Process Technol, 8:5 DOI: 10.4172/2157-7110-C1-061.

Harrigan, W.F. (1998) Laboratory Methods in Food Microbiology. Academic Press, 525 B Street, Suit 1900, San Diego, California, 92101-4495, USA.

Hilborn, E.D. and Beasley, V.R. (2015). One health and cyanobacteria in freshwater systems: animal illnesses and deaths are sentinel events for human health risks. Toxins, 7(4): 1374-1395. http://doi.org/10.3390/toxins7041374.

Holst, T.; Jorgensen, N.; Jorgensen, C. and Johansen. A. (2003). Degradation of microcystin in sediments at oxic and anoxic, denitrifying conditions. Water Research, 37: 4748-4760.

Jastaniah, O,R, (2010). Elements of environmental pollution in Jeddah corniche, from a perspective of tourism and recreation geography. Journal of King Abdulaziz. University, 21(2): 237-266.

Kitto, M.R. and Sambhu, C. (2012). Litter pollution on the coastline of obhur, Kingdom of Saudi Arabia. Arab Gulf Journal of Scientific Research, 30(2/3): 112-119.

Larson, D.; Ahlgren, G. and Willén, E. (2014). Bioaccumulation of microcystins in the food web: a field study of four Swedish lakes. Inland Waters, 4: 91-104.

Li, J.; Li, R. and Li, J. (2017). Current research scenario for microcystins biodegradation - a review on fundamental knowledge, application prospects and challenges. Sci.Total Environ. $\quad 595 \quad$ (Suppl. C), 615-632. https://doi.org/10.1016/j.scitotenv.2017.03.285.

Li, Y.; Chen, J.; Zhao, Q.; Pu, C.; Qiu, Z.; Zhang, R. and Shu, W. (2011). A cross-sectional investigation of chronic exposure to microcystin in relationship to childhood liver damage in the Three Gorges Reservoir region, China. Environ. Health Perspect, 119 (10): 1483-1488.

Liska, A.J.; Shevhenko, A.; Pick, U. and Katz, A., (2004). Enhanced photosynthesis and redox energy production contribute to salinity tolerance in Dunaliella as revealed by homology-based proteomics. Plant Physiol, 136: 28062817.

Lone, Y.; Koiri, R.K. and Bhide, M. (2015). An overview of the toxic effect of potential human carcinogen Microcystin-LR on testis. Toxicology Reports, 2: 289-296.

Martin-Luna, B.; Sevilla, E.; Bes, M.T.; Fillat, M.F. and Peleato, M.L. (2015). Variation in the synthesis of microcystin in response to osmotic stress in Microcystis aeruginosa PCC7806. Limnetica, 34 (1): 205-214.

McGenity, T.J. and Oren, A. (2012). Hypersaline environments. In Life at Extremes: Environments, Organisms and Strategies for Survival. EM Bell (ed.) CAB International, UK., 402-437.

Mishra, P.; Singh, V.P. and Prasad, S.M. (2014). Spirulina and its nutritional importance: A possible approach for development of functional food. Biochem Pharmacol, 3: e171. doi:10.4172/2167-0501.1000e171.

Niranjana, R.; Gayathri, R.; Stephen, N.M.; Sugawara, T.; Hirata, T.; Myashita, K. and Ganesan, P. (2015). Carotenoids modulate the hallmarks of cancer cells.
Journal of Functional Foods, 18: 968-985. DOI: 10.1016/j.jff.2014.10.017.

Oren, A. (2005). A hundred years of Dunaliella research: 1905-2005. BMC Saline Systems, 1:2 doi:10.1186/17461448-1-2.

Preece, E.P.; Hardy, F.J.; Moore, B.C. and Bryan, M. (2017). A review of microcystin detections in Estuarine and Marine waters: Environmental implications and human health risk Harmful. Algae, 61: 31-45.

Rasul, N.M.A.; Stewart, I.C.F. and Nawab, Z.A. (2015). Introduction to the Red Sea: Its Origin, Structure, and Environment. In: Rasul N., Stewart I. (eds) The Red Sea. Springer Earth System Sciences. Springer, Berlin, Heidelberg pp1-28.

Sathasivam, R. Radhakrishnan, R.; Hashem, A. and Abd_Allah, E.F. (2018). Microalgae metabolites: A rich source for food and medicine, Saudi Journal of Biological Sciences. Article in press https://doi.org/10.1016/j.sjbs.2017.11.003.

Stewart, I.; Webb, P.M.; Schluter, P.J. and Shaw, G.R. (2006). Recreational and occupational field exposure to freshwater cyanobacteria - a review of anecdotal and case reports, epidemiological studies and the challenges for epidemiologic assessment. Environ Health, 5: 6. doi: 10.1186/1476-069X-5-6.

Welker, M. and Steinberg, C. (2000). Rates of Humic Substance Photosensitized Degradation of Microcystin-LR in Natural Waters. Environ. Sci. Technol., 34: 3415-3419.

White, S.H.; Duivenvoorden, L.J. and Fabbro, L.D. (2005). A decision-making framework for ecological impacts associated with the accumulation of cyanotoxins (cylindrospermopsin and microcystin) Lake Reserv. Res. Manag. 10: 25-37. doi: 10.1111/j.14401770.2005.00258.x.

WHO (2004). Guidelines for Drinking-Water Quality, 3rd Ed., Vol. 1, Recommendations, World Health Organization, Geneva.

WHO, World Health Organization (1999). Toxic Cyanobacteria in Water: A Guide to their Public Health Consequences, Monitoring, and Management, I. Chorus and J. Bartram, (Eds.). E\&FN Spon, London, UK.

Xu, Y.; Ibrahim, I.M.; Wosu, C.I.; Ben-Amotz, A. and Harvey, P.J. (2018) Potential of New Isolates of Dunaliella Salina for Natural $\beta$-Carotene Production Biology 2018, 7: 14 doi:10.3390/biology7010014.

Ye, J. ; Du. Y. ; Wang, L.; Qian, J.; Chen, J.; Wu, Q. and Hu, X. (2017). Toxin Release of Cyanobacterium Microcystis aeruginosa after Exposure to Typical Tetracycline Antibiotic Contaminants. Toxins, 9(2): 53. http://doi.org/10.3390/toxins9020053.

Zastepa, A. (2014). Fate and persistence of microcystin congeners in lakes and lake sediments, Ph.D Thesis, Faculty of Biology, Ottawa-Carlton Institute of Biology, Ottawa University, Canada. http://dx.doi.org/10.20381/ruor-4280.

Zastepa, A.; Pick, F.R.; Blais, J.M. and Saleem A. (2015). Analysis of intracellular and extracellular microcystin 
variants in sediments and pore waters by accelerated solvent extraction and high performance liquid chromatography-tandem mass spectrometry. Analytica Chimica Acta, 2015, 872: 26-34. https://doi.org/10.1016/j.aca.2015.02.056.
Zurawell, R.W.; Chen, H.; Burke, J.M. and Prepas, E.E. (2005). Hepatotoxic cyanobacteria: A review of the biological importance of microcystins in freshwater environments. J. Toxicol. Environ. Health B, 8:1-37. 
التقصي البيولوجي والكيميائي لجودة المياه ودراسة التلوث بعد ازدهار طحالب مشتبه

$$
\text { فيها في بحيرة ساحلية }
$$

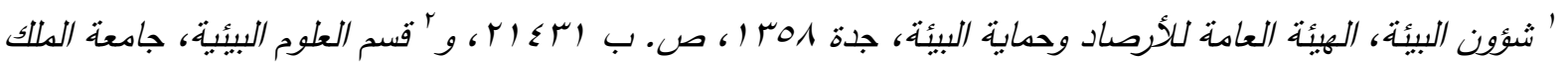

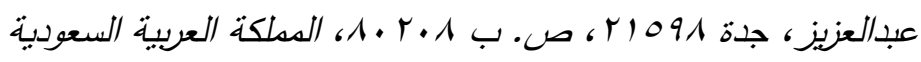

الدستخلص. الاشتباه في تلوث بحيرة السمكة بالقرب من أبحر على خط جدة الساحلي

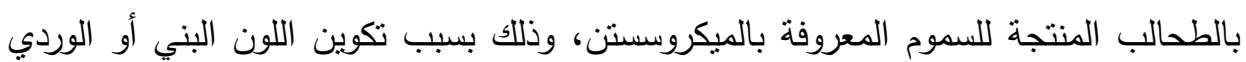

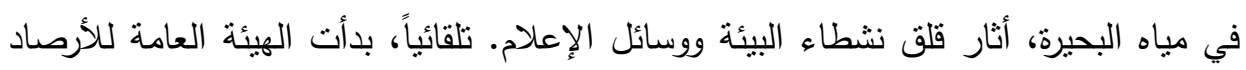
وحماية البيئة (GAMEP) بالتحقيق في المشكلة البيئية في البحيرة. تم جمع عينات مياه من البعاه البحيرة من مناطق أخذ عينات مختلفة تغطي جميع الاتجاهات. نم تحليل العينات لنقدير

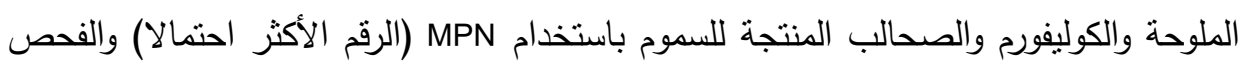

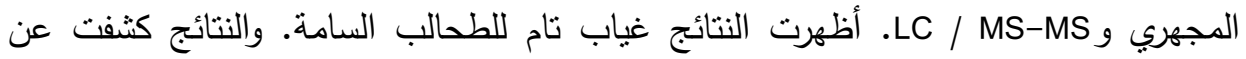

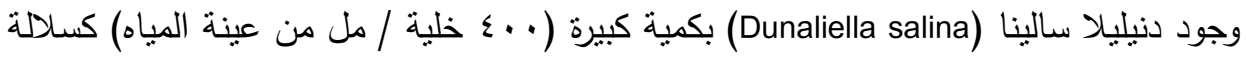

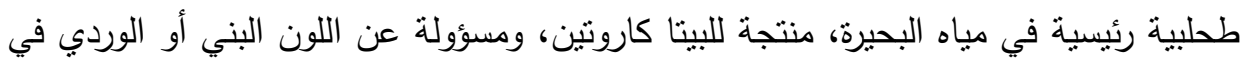
البحيرة. كلمات مفتاحبة: بحيرة شاطئية ساحلية، ازدهار الطحالب، دنيليلا سالينا، جدة. 